\title{
PREFERENCJE ŻYWIENIOWE STUDENTÓW KIERUNKU PIELĘGNIARSTWO
}

\section{Food preferences of nursing faculty students}

\author{
MONIKA SANDER - GRABOWSKA ${ }^{1}$, BEATA PRZYSTAŚ ${ }^{1}$, ELŻBIETA \\ SZUDY ${ }^{1}$, BEATA HAOR ${ }^{2}$
}

\author{
${ }^{1}$ Studenckie Koło Naukowe Nauk o Zdrowiu, Instytut Nauk o Zdrowiu PWSZ \\ we Włocławku \\ ${ }^{2}$ Instytut Nauk o Zdrowiu PWSZ we Włocławku
}

DOI: http://dx.doi.org/10.21784/IwP.2018.010

ISSN: 2451-1846

\section{Streszczenie:}

Wstęp. Elementarnym czynnikiem wpływającym na zdrowie człowieka jest prawidłowe odżywianie.

Cel. Celem pracy była analiza preferencji żywieniowych studentów pierwszego roku kierunku pielęgniarstwo.

Materiał i metody. Do badań wykorzystano metodę sondażu diagnostycznego, a jako narzędzie badawcze kwestionariusz Inwentarza Zachowań Zdrowotnych (IZZ). Badania zostały przeprowadzone wśród studentów pierwszego roku kierunku pielęgniarstwo.

Wyniki. Badani studenci w większości zdawali sobie sprawę z wpływu zdrowego odżywiania na zachowanie zdrowia.

Wnioski. Osoby w przedziale wiekowym 20-25 lat i 31 lat i więcej jedzą więcej warzyw i owoców oraz unikają żywności $\mathrm{z}$ konserwantami. Najmłodsza grupa studentów spożywa więcej pieczywa pełnoziarnistego oraz ogranicza spożycie soli i tłuszczów zwierzęcych.

Słowa kluczowe: sposób odżywiania, pielęgniarstwo, studenci

\section{Abstract:}


Introduction. Healthy nutrition is a factor of elementary importance on human health.

Aim. This thesis aims to analyse food preferences of first-year students of nursing faculty.

Materials and methods. The diagnostic survey was used to collect the data and the questionnaire of the Inventory of Healthy Behaviours was used as a research instrument. The research was conducted among first-year students of nursing faculty.

Results. The majority of students recognised the importance of healthy nutrition on maintaining health.

Conclusions. People of $20-25$ years of age as well as those of 31years of age eat more fruit and vegetables and they avoid eating food with preservatives. The youngest group of students eats more wholegrain bread and limits the intake of salt and animal fats.

Keywords: nutrition, students, nursing

\section{Wstęp}

Zdrowie stanowi największą wartość i rodzaj specyficznego bogactwa, a zarazem prawo człowieka wymagające zdecydowanej ochrony. Jest ono zasobem życiowym, obejmującym zasoby osobiste i społeczne oraz możliwości fizyczne. Według Światowej Organizacji Zdrowia (WHO), zdrowie to stan pełnego, dobrego samopoczucia fizycznego, psychicznego i społecznego, a nie tylko brak choroby. Styl życia w 50\% wpływa na nasze zdrowie. Pozostałe czynniki to: środowisko (20\%), czynniki genetyczne (20\%), opieka zdrowotna (10\%) [1].

Zachowania zdrowotne są to zwyczaje i nawyki determinujące stan zdrowia jednostki. Niektórzy badacze dzielą zachowania zdrowotne na takie, które służą zdrowiu np. zdrowe odżywianie, regularna aktywność fizyczna czy odpowiednia długość snu, nazywając je inaczej „immunogenami zdrowia” oraz na zachowania zdrowotne stwarzające ryzyko dla zdrowia, określane jako „behawioralne patogeny" [2]. Do takich patogenów zaliczane są: palenie tytoniu, picie 
nadmiernych ilości alkoholu czy spożywanie żywności o dużej zawartości tłuszczu. Istotną rolę $\mathrm{w}$ prozdrowotnym stylu życia odgrywa właściwa dieta, która ma pozytywny wpływ na rozwój i funkcjonowanie człowieka, zaspokajając jego potrzeby biologiczne, psychospołeczne. Niewłaściwe odżywianie stanowi bezpośrednią przyczynę wielu chorób [3, 4].

Zdobywanie wiedzy o zdrowiu ma swój początek w rodzinie a następnie jest kontynuowane m.in. w toku edukacji, oddziaływania szeregu instytucji a także grup rówieśniczych, przyjaciół. Mają one zdecydowany wpływ na formowanie i reformowanie ludzkich postaw i zachowań. Nieprawidłowości w strukturze spożycia żywności u dzieci i młodzieży prowadzą do zbyt niskiej lub zbyt wysokiej wartości energetycznej posiłków, nadmiernego udziału tłuszczów i sacharozy, zbyt niskiej zawartości błonnika, cynku, magnezu, miedzi, wapnia i żelaza oraz witamin z grupy B, witamin C, D w diecie. Wymienione czynniki wraz $\mathrm{z}$ niską aktywnością fizyczną należą do najistotniejszych przyczyn występowania w Polsce przewlekłych chorób niezakaźnych: otyłości, nadciśnienia tętniczego, cukrzycy typu 2 oraz próchnicy zębów. Prewencja chorób cywilizacyjnych skupia się przede wszystkim na promocji zachowań prozdrowotnych, $\mathrm{w}$ tym zdrowego i racjonalnego odżywiania się, systematycznej aktywności fizycznej oraz wykonywania okresowych badań przesiewowych [5].

Celem pracy jest analiza preferencji żywieniowych studentów pierwszego roku kierunku pielęgniarstwo.

\section{Materiał i metody}

Badania przeprowadzono wśród 22 studentów I roku kierunku pielęgniarstwo (studia stacjonarne) w Państwowej Wyższej Szkole Zawodowej we Włocławku w roku akademickim 2017/2018. W badaniu wykorzystano metodę sondażu diagnostycznego oraz metodę szacowania, a także technikę ankietowania i technikę skali szacunkowej. Jako narzędzie badawcze wykorzystano Kwestionariusz 
Inwentarza Zachowań Zdrowotnych (IZZ), zakupiony w Pracowni Testów Psychologicznych. Analizie poddano odpowiedzi respondentów odnoszące się do nawyków żywieniowych. Udział w badaniach był anonimowy i dobrowolny. Dane zebrano w arkuszu kalkulacyjnym Microsoft Excel 2003; określono udział procentowy odpowiedzi, a także liczbę punktów i ich średnią uzyskaną przez badanych. Wyniki zostały przedstawione $\mathrm{w}$ formie rycin i tabel.

W badanej grupie przeważały osoby w przedziale wiekowym 19 lat i mniej oraz 31 lat i więcej, odpowiednio 36,36\% (8 osób) i 36,36\% (8 osób). Respondenci w wieku 20-25 stanowili 27,27\% badanych (6 osób). Wśród studentów nie było żadnej osoby w przedziale wiekowym 26-30 lat (rycina 1 i wykres 1 ).

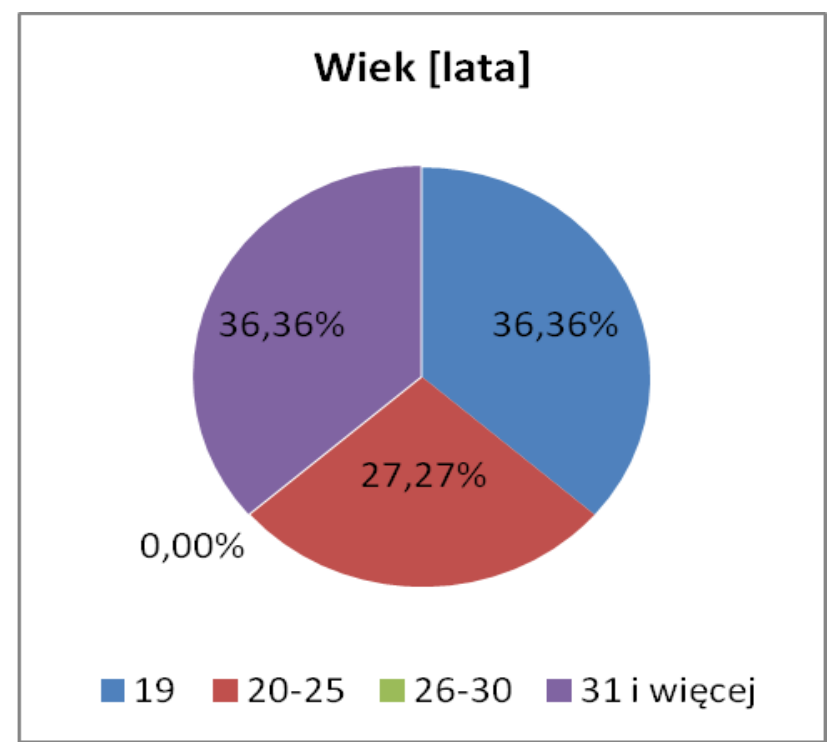

\section{Rycina 1. Wiek badanej grupy.}

Źródło: wyniki badań własnych 


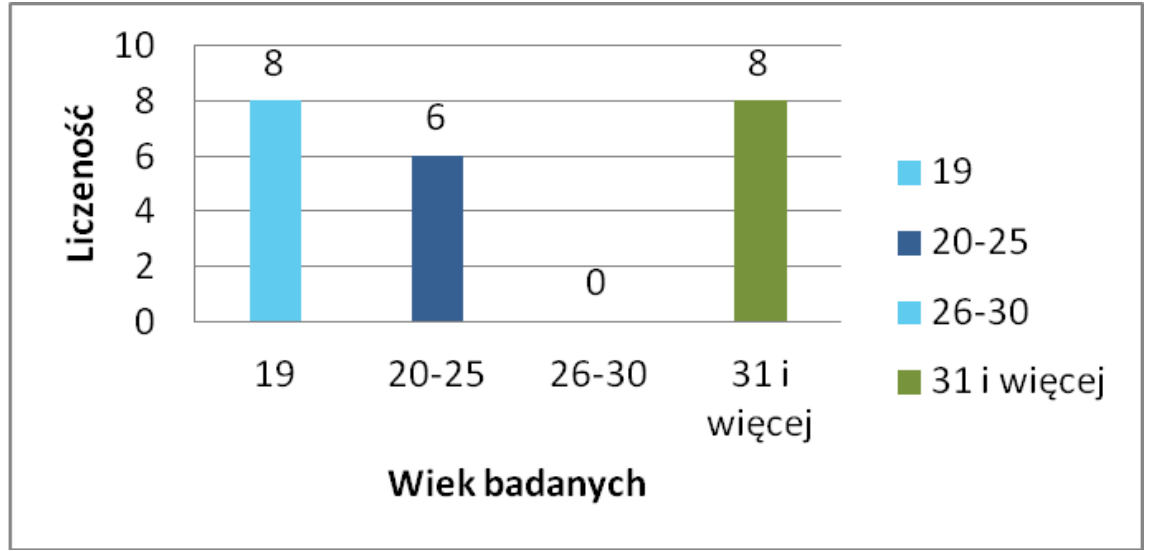

Wykres 1. Liczebność badanej grupy.

Źródło: wyniki badań własnych

Analizie poddano odpowiedzi respondentów na następujące pytania:

1. Czy jem dużo warzyw, owoców?

2. Czy ograniczam spożywanie takich produktów, jak tłuszcze zwierzęce, cukier?

3. Czy dbam o prawidłowe odżywianie?

4. Czy unikam spożywania żywności z konserwantami?

5. Czy unikam soli i silnie solonej żywności?

6. Czy jem pieczywo pełnoziarniste?

Badani udzielali odpowiedzi wybierając ich następujące warianty: prawie nigdy, rzadko, od czasu do czasu, często, prawie zawsze.

\section{Wyniki}

Tabela 1 stanowi zbiorczy obraz preferencji żywieniowych studentów $\mathrm{z}$ podziałem na kategorie wiekowe. Największą liczbę punktów w tym zakresie uzyskiwali studenci z grupy wiekowej 20-25 lat. 
Tabela 1. Preferencje żywieniowe badanych ze względu na wiek

\begin{tabular}{|c|c|c|c|c|c|c|}
\hline $\begin{array}{l}\text { Kategoria } \\
\text { zachowań }\end{array}$ & \multicolumn{6}{|c|}{ Nawyki żywieniowe } \\
\hline $\begin{array}{l}\mathrm{Nr} \\
\text { pytania }\end{array}$ & 1 & 5 & 9 & 13 & 17 & 21 \\
\hline $\begin{array}{l}\text { Treść } \\
\text { pytania }\end{array}$ & $\begin{array}{l}\text { Jem } \\
\text { dużo } \\
\text { warzyw, } \\
\text { owoców }\end{array}$ & $\begin{array}{l}\text { Ograniczam } \\
\text { spożywanie } \\
\text { takich } \\
\text { produktów, } \\
\text { jak tłuszcze } \\
\text { zwierzęce, } \\
\text { cukier }\end{array}$ & $\begin{array}{l}\text { Dbam o } \\
\text { prawidł } \\
\text { owe } \\
\text { odżywi } \\
\text { anie }\end{array}$ & $\begin{array}{l}\text { Unikam } \\
\text { spożywa } \\
\text { nia } \\
\text { żywności } \\
\text { z } \\
\text { konserwa } \\
\text { ntami }\end{array}$ & $\begin{array}{l}\text { Unikam } \\
\text { soli i } \\
\text { silnie } \\
\text { solonej } \\
\text { żywności }\end{array}$ & $\begin{array}{l}\text { Jem } \\
\text { pieczywo } \\
\text { pełnoziar } \\
\text { niste }\end{array}$ \\
\hline $\begin{array}{l}\text { Wiek } \\
\text { [lata] }\end{array}$ & \multicolumn{6}{|c|}{ Średnia liczba punktów } \\
\hline 19 i mniej & 3,62 & 2,5 & 3,25 & 2,75 & 2,75 & 3,0 \\
\hline $20-25$ & 4,0 & 4,0 & 4,0 & 3,33 & 4,0 & 4,5 \\
\hline $26-30$ & 0 & 0 & 0 & 0 & 0 & 0 \\
\hline $\begin{array}{ll}31 & \text { i } \\
\text { więcej } & \end{array}$ & 4,2 & 3,25 & 3,37 & 3,5 & 3,37 & 4,0 \\
\hline
\end{tabular}

\section{Źródło: wyniki badań własnych}

Respondenci w wieku 20-25 lat zebrali największą liczbę punktów odpowiadając na pytania: ograniczam tłuszcze zwierzęce i cukier ( 4 pkt.), dbam o prawidłowe odżywianie (4 pkt.), unikam soli i silnie solonej żywności (4 pkt.), jem pieczywo pełnoziarniste $(4,5$ pkt.). W grupie wiekowej 31 lat i więcej studenci uzyskali największą liczbę punktów odpowiadając na pytania: jem dużo warzyw i owoców (4,2 pkt.), unikam spożywania żywności z konserwantami (3,5 pkt.). Najniższą ilość punktów zdobyli studenci w wieku 19 lat i poniżej udzielając odpowiedzi następujące na pytania: jem dużo warzyw 
i owoców - 3,62 pkt., dbam o prawidłowe odżywianie - 3,25 pkt., jem pieczywo pełnoziarniste - 3 pkt., unikam spożywania żywności z konserwantami oraz unikam soli i silnie solonej żywności odpowiednio po 2,75 pkt., ograniczam spożywanie takich produktów, jak tłuszcze zwierzęce, cukier - 2,5 pkt. (wykres 2, tabela 1).

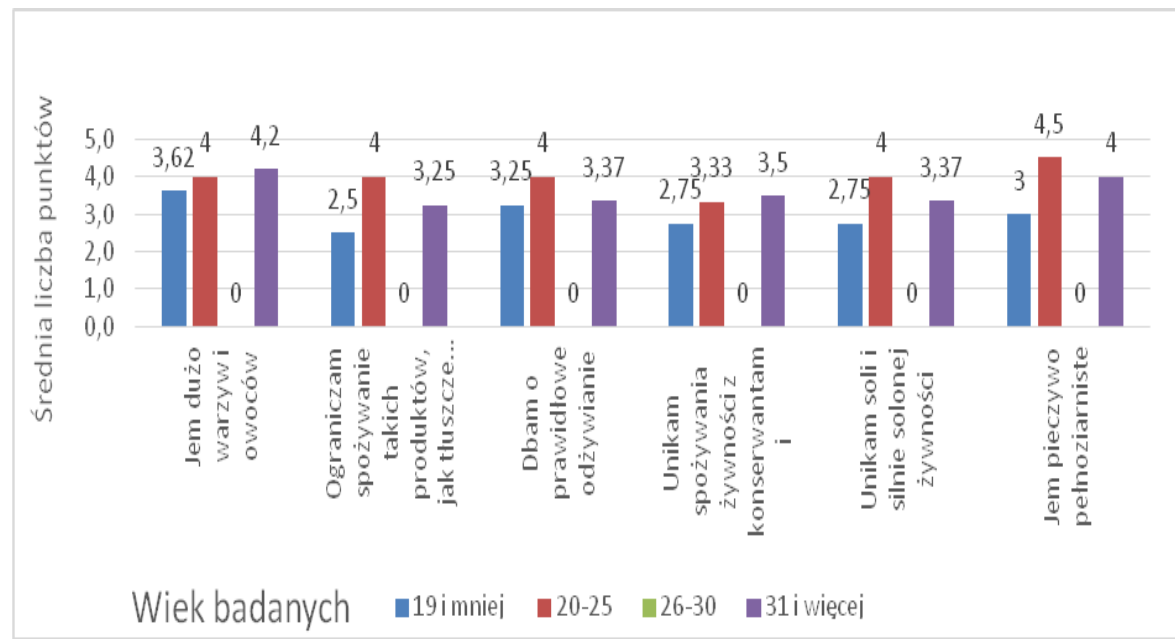

Wykres 2. Preferencje żywieniowe badanych ze względu na wiek.

Źródło: wyniki badań własnych

Jak wynika z wykresu 3, ponad połowa ankietowanych ze wszystkich grup wiekowych często spożywa warzywa i owoce. W najmłodszej grupie wiekowej jedynie 1 osoba $(12,5 \%)$ odpowiedziała, że czyni to rzadko. W przedziale wiekowym 19 i mniej prawie zawsze sięga po owoce i warzywa $12,5 \%$ (1 osoba), w przedziale $20-25$ lat - 16,67\% (1 osoba), natomiast w najstarszej grupie wiekowej 31 i więcej - 37,5\% (3 osoby). 


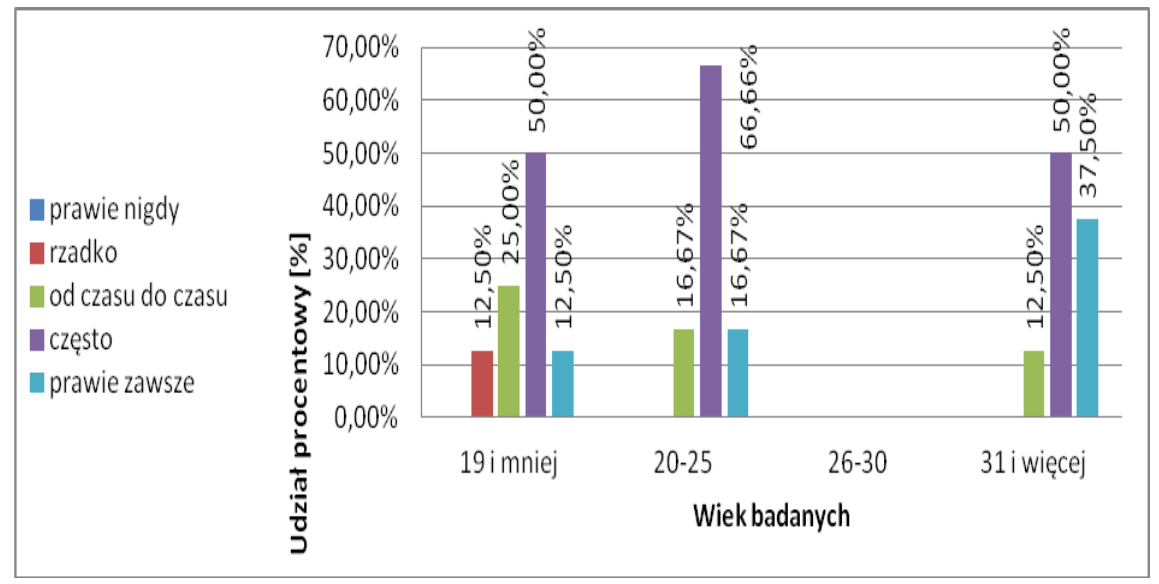

Wykres 3. Jem dużo warzyw, owoców.

Źródło: wyniki badań własnych

Kolejnym analizowanym aspektem było ograniczenie spożycia takich produktów, jak tłuszcze zwierzęce i cukier. Tutaj odpowiedzi nie były jednoznaczne. Połowa 19-latków nie ogranicza spożycia tych produktów. Natomiast pozostali respondenci czynią to tylko okazjonalnie a jedynie 1 osoba (12,5\%) - często. Większą świadomość w tym zakresie posiadają 20-25-latki bowiem 66,66\% (6 osób) ogranicza spożycie tłuszczów zwierzęcych i cukru zawsze lub prawie zawsze. Z kolei $33,33 \%$ badanych ( 2 osoby) robi to od czasu do czasu. Rzadko lub tylko od czasu do czasu zadeklarowała ograniczenie spożycia tłuszczów i cukru połowa 31-latków, a 37,5\% (3 osoby) czyni to często (wykres 4). 


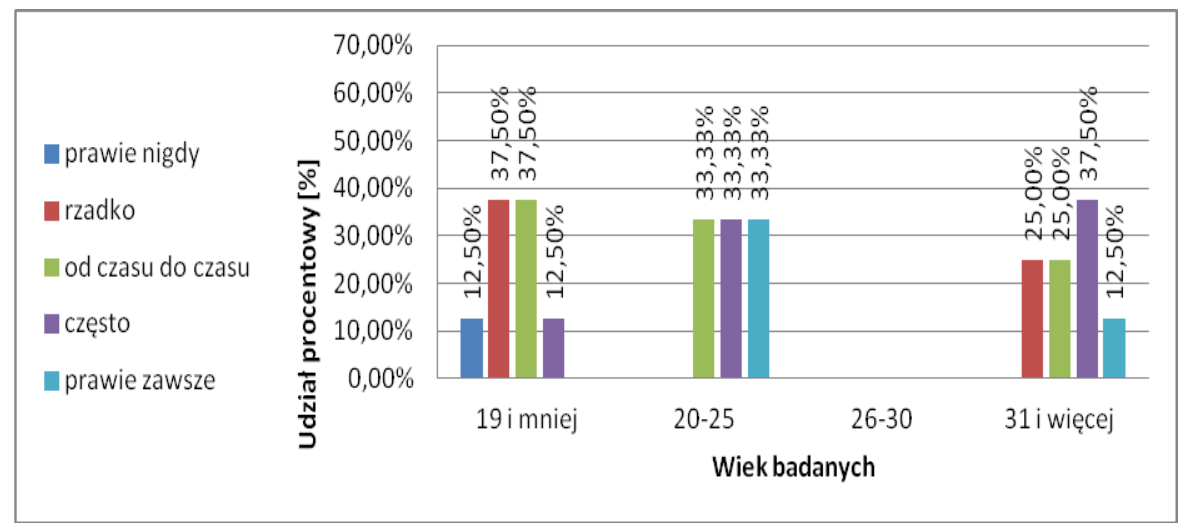

Wykres 4. Ograniczam spożywanie takich produktów, jak tluszcze zwierzęce, cukier.

Źródło: wyniki badań własnych

O prawidłowe odżywianie dba jedynie 37,5\% 19-latków (3 osoby), natomiast $25 \% \mathrm{z}$ nich ( 2 osoby) nie robi tego wcale. Zdecydowana większość respondentów (62,5\%) z grupy wiekowej 31 i więcej (5 osób) odżywia się prawidłowo, a jedynie 1 osoba (12,5\%) odpowiedziała, że nie robi tego prawie nigdy. W grupie wiekowej 2025 lat odpowiedzi rozłożyły się równomiernie - po 33,33\% - 2 osoby dbają o prawidłowe odżywianie od czasu do czasu, 2 osoby czynią to często a 2 osoby prawie zawsze (wykres 5).

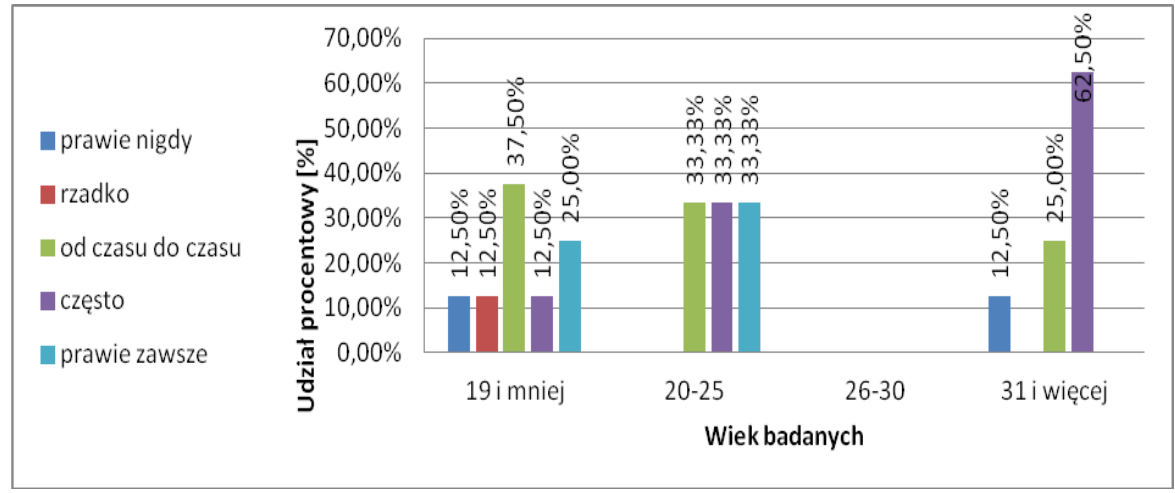

Wykres 5. Dbam o prawidłowe odżywianie.

Źródło: wyniki badań własnych 
Wykres 6 przedstawia preferencje żywieniowe respondentów dotyczące unikania spożywania żywności z konserwantami przez respondentów. Większość 19-latków (62,5\% -5 osób) robi to od czasu do czasu, bądź często unika żywności przetworzonej, prawie zawsze czyni to 33,33\% (2 osoby) 20-25-latków. Połowa respondentów w wieku 20-25 lat (3 osoby) korzysta $\mathrm{z}$ takiej żywności od czasu do czasu. Żywność z konserwantami spożywa 25\% respondentów (2 osoby) w przedziale wiekowym 31 lat i więcej.

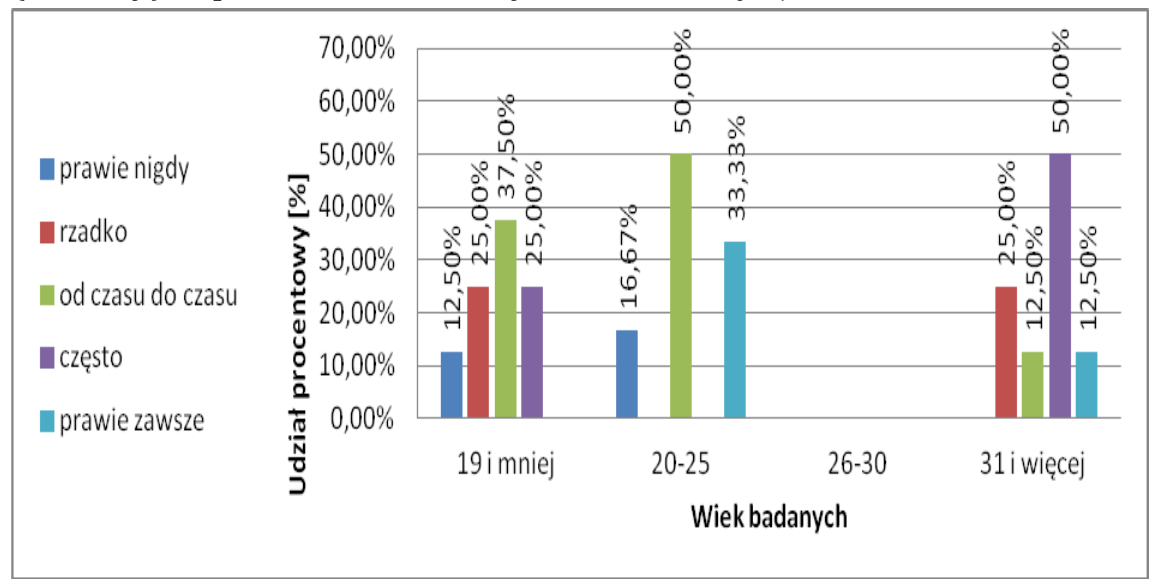

\section{Wykres 6. Unikam spożywania żywności z konserwantami.}

Źródło: wyniki badań własnych

Jak wynika z wykresu 7 - 25\% 19-latków (2 osoby), 33,33\% 20-25-latków (2 osoby) i 50\% 31-latów (4 osoby) odpowiedziała, że często unika spożywania soli i silnie solonej żywności. Prawie nigdy lub rzadko czyni to 25\% 19-latków (2 osoby) i 1 student w grupie 31 latków (12,5\%) (wykres 7). 


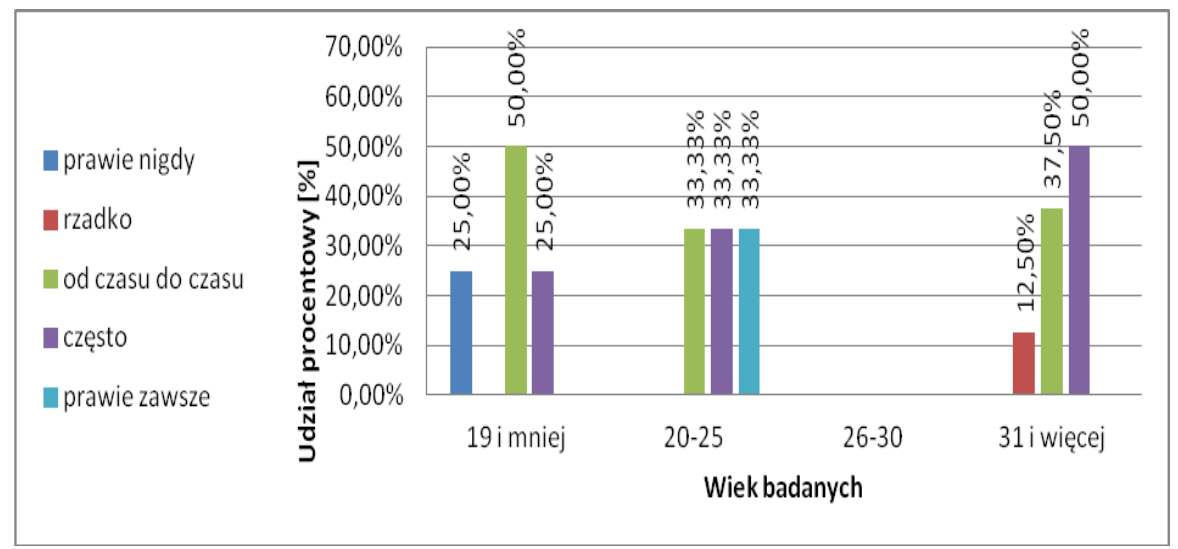

\section{Wykres 7. Unikam soli i silnie solonej żywności.}

Źródło: wyniki badań własnych

Ostatnie pytanie poddane analizie $\mathrm{w}$ ankiecie dotyczyło spożywania pieczywa pełnoziarnistego. Najwięcej osób, które nie sięga po pieczywo z ziarnem dotyczyło najmłodszej i najstarszej grupy respondentów - odpowiednio 12,5\% (1 osoba) i 25\% (2 osoby). Ponad połowa 19-latków (62,5\%- 5 osób) spożywa takie pieczywo jedynie okazjonalnie. Wszyscy respondenci z przedziału wiekowego 20-25 lat jedzą pieczywo pełnoziarniste, natomiast w najstarszej grupie czyni to 62,5\% badanych (5 osób) (wykres 8).

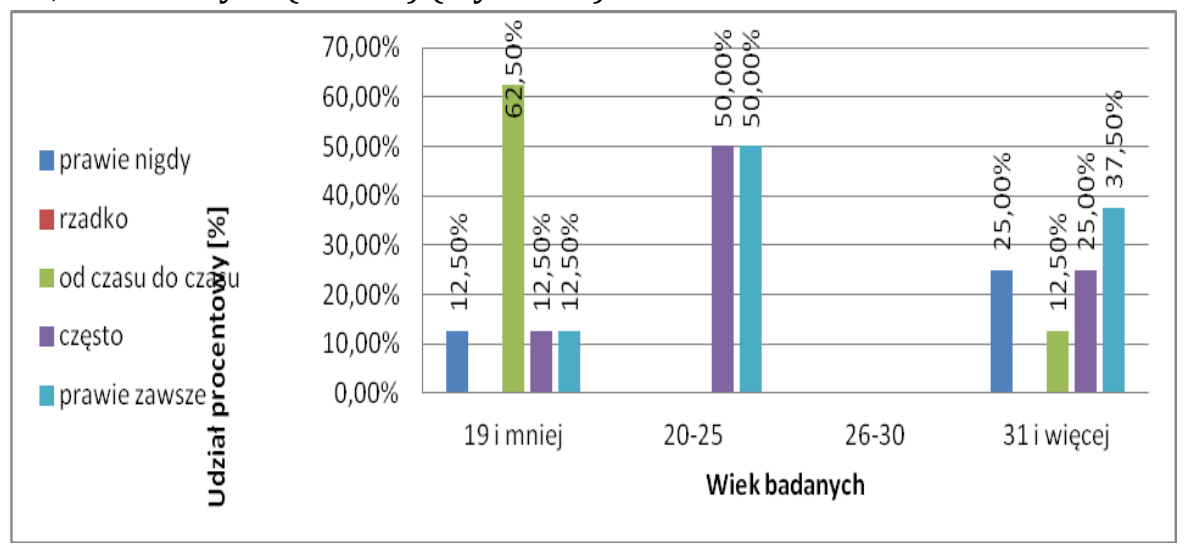

\section{Wykres 8. Jem pieczywo pelnoziarniste.}

Źródło: wyniki badań własnych 


\section{Dyskusja}

Wyniki badań z zastosowaniem kwestionariusza (IZZ) wykazują, że studenci I roku kierunku pielęgniarstwo reprezentują zróżnicowany poziom zachowań prozdrowotnych, $\mathrm{z}$ tendencją do zwracania uwagi na styl życia, a w szczególności na zdrowy sposób odżywiania. Jest to bardzo istotne z punktu widzenia wykonywanego w przyszłości zawodu. Od przedstawicieli zawodów medycznych wymaga się bowiem wiedzy i kompetencji w kształtowaniu prawidłowych nawyków mających wpływ na zdrowie człowieka. Edukacja społeczeństwa w zakresie zdrowego stylu życia odbywa się także dzięki programom profilaktycznym i kampaniom społecznym a współcześnie szczególnie poprzez środki masowego przekazu, w tym media społecznościowe [6].

Jak wynika z przeprowadzonych badań własnych respondenci mają świadomość wpływu prawidłowego odżywiania na zdrowie i starają się przestrzegać tych zasad na co dzień jedząc owoce i warzywa, pełnoziarniste pieczywo, ograniczając spożycie produktów zawierających: tłuszcze zwierzęce, cukier, sól, konserwanty.

Z badań WOBASZ (Wieloośrodkowe ogólnopolskie badanie stanu zdrowia ludności) wynika, że spożycie tłuszczów wśród ludności w Polsce, znacznie przekracza zalecaną dawkę dziennego zapotrzebowania, natomiast korzystanie z produktów zbożowych jest niższe od zalecanego. Jedynie spożycie owoców i warzyw w większości badanych województw można uznać za zadowalające, ponieważ przekroczyło ono minimalną zalecaną dawkę (400g) [7]. Z badań GUS (Główny Urząd Statystyczny) z 2014r. wynika, że spożycie owoców deklarowało 59\% a warzyw 57\% dorosłych mieszkańców Polski [8]. Dane WOBASZ i GUS wskazują jednak na to, że spożycie warzyw i owoców jest nadal niewystarczające wśród polskiej ludności.

Biorąc pod uwagę fakt, że studenci podczas dalszej nauki będą kształtowali kompetencje w zakresie promowania prawidłowych zachowań prozdrowotnych, powinni oni zwrócić szczególną uwagę 
na działania mające na celu zwiększenie spożycia owoców i warzyw. Prowadzenie prawidłowego stylu życia należy rozpocząć od siebie, rodziny i najbliższego otoczenia, co będzie miało przełożenie na wzrost świadomości społeczeństwa w tym zakresie [9].

Działania zmierzające do zmiany zachowań zdrowotnych polskiej populacji zostały uwzględnione w założeniach NPZ (Narodowy Program Zdrowia na lata 2016-2020), którego cele operacyjne obejmują: poprawę sposobu żywienia, stanu odżywiania oraz promocję aktywności fizycznej wśród Polaków [10].

\section{Wnioski}

Przeprowadzone badanie pozwoliły na sformułowanie następujących wniosków:

1. Osoby w przedziale wiekowym 20-25 lat i 31 lat i więcej, jedzą więcej warzyw i owoców oraz unikają żywności z konserwantami.

2. Najmłodsza grupa studentów spożywa więcej pieczywa pełnoziarnistego oraz ogranicza spożycie soli i tłuszczów zwierzęcych.

3. Wszystkie grupy badanych wykazują wiedzę na temat wpływu prawidłowego odżywiania na stan zdrowia.

\section{Zalecenia dla praktyki pielęgniarskiej}

Studenci pielęgniarstwa wykazujący prawidłowe nawyki żywieniowe będą w stanie w przyszłości propagować wśród swoich pacjentów pozytywne postawy w zakresie racjonalnego żywienia.

\section{Bibliografia/Bibliography:}

1. Heszen I., Sęk H. Psychologia zdrowia. Wyd. Naukowe PWN, Warszawa 2007. 
2. Heszen I., Sęk H. Behawioralne uwarunkowania zdrowia i choroby. W: Psychologia zdrowia. Heszen I., Sęk H. (Red). Wyd. Naukowe PWN, Warszawa 2012; 90-104.

3. Raport $\mathrm{z}$ badań. Polacy o swoim zdrowiu oraz prozdrowotnych zachowaniach i aktywnościach. CBOS, Warszawa 2012.

4. Kulik B., Latalski M. Zdrowie publiczne. Podręcznik dla studentów i absolwentów wydziałów pielęgniarstwa i nauk o zdrowiu akademii medycznych. Czelej, Lublin 2002.

5. Gawęcki J., Roszkowski W. Żywienie człowieka a zdrowie publiczne. T. 3. Wyd. Naukowe PWN, Warszawa 2018; 223-228.

6. Nowak P.F., Chalimoniuk-Nowak M. Potencjał mediów społecznościowych w edukacji zdrowotnej. W: Wolska Adamczyk A. (Red.) Współczesne kierunki działań prozdrowotnych. WSIiZ, warszawa 2015: 35-45.

7. Sygnatowska E. i wsp. Spożycie produktów spożywczych przez dorosłą populację Polski. Wyniki programu WOBASZ. Kardiologia Polska. 2005; 63:6 (supl. 4): 1-7.

8. GUS, Stan zdrowia ludności Polski w 2014r. Warszawa 2016: 88-89

9. Wojnarowska B. Edukacja zdrowotna. PWN, Warszawa 2017.

10. Rozporządzenie Rady Ministrów z dnia 4 sierpnia 2016 r. w sprawie Narodowego Programu Zdrowia na lata 2016-2020. Dz. U. 2016r. poz. 1492. 